\title{
Queer necropolitics of asylum: Senegalese refugees facing HIV in Mauritania
}

Christophe Broqua ${ }^{1}$ (CNRS-IMAF, Aubervilliers)

Gabrièle Laborde-Balen (IRD-UMI TransVIHMI, CRCF, Dakar)

Agathe Menetrier (MPI for Social Anthropology, Halle / ENS, Paris)

Djamil Bangoura (Prudence+, Dakar)

\begin{abstract}
:
Since 2008, homosexuality has been the subject of recurrent public controversies in Senegal, sometimes accompanied by police arrests and popular violence. In this context, a migration route has opened up to Mauritania, where some are granted refugee status by the United Nations High Commissioner for Refugees (UNHCR). Among them, a few are selected for 'resettlement' in a host country in North America or Europe. Many of these Senegalese gay men residing in Mauritania are infected with HIV. In recent years, some of them have returned to Senegal in a very deteriorated condition, leading in several cases to death; others have died in exile in Nouakchott. This article reports on the living conditions and access to health care of Senegalese gay men who went to Mauritania hoping for resettlement to the Global North by the UNHCR. It is based on semi-directed interviews with Senegalese gay asylum seekers as well as members of NGOs, health structures and institutions (including the UNHCR) in Nouakchott and Dakar. It shows that, despite the UNHCR's demonstrated commitment to refugee protection, the asylum (and specifically resettlement) system exposes those who rely on it to increased, sometimes fatal, health risks.
\end{abstract}

\footnotetext{
${ }^{1}$ Contact: christophe.broqua@cnrs.fr
} 


\section{Keywords:}

asylum; queer; HIV; necropolitics; Senegal, Mauritania 
Between 2013 and 2018, we learned of more than 20 young Senegalese gay men ${ }^{2}$ who died of AIDS in Dakar. Most of them had stopped their antiretroviral therapy (ART) during a trip abroad, most often to Mauritania, where they had gone into exile to escape homophobic harassment and violence. Some were infected with HIV and treated before leaving; others became infected while in exile.

Senegal was one of the first countries in Africa to make ART accessible free of charge, and one of the first countries in Africa to take action on behalf of gay men in the fight against HIV. The phenomenon of these young men returning sick to Dakar is therefore not only alarming but also surprising. Why are Senegalese gay men residing in Mauritania? What kind of lives do they build for themselves there and, more specifically, why do they find themselves in such critical health situations?

If these Senegalese gay men fled to Mauritania, it was to seek asylum through the United Nations High Commissioner for Refugees (UNHCR) in Nouakchott and reach Europe or North America through its resettlement programme. While no official statistics are available, we estimate that approximately 100 Senegalese asylum seekers and refugees have resided in Nouakchott at any given time since the mid-2010s. ${ }^{3}$ Alerted by the death cases and the critical health situations we witnessed during three rounds of fieldwork in Nouakchott, we wondered what it was about these flight trajectories that put them at increased risk of HIV-related death. We were faced with what

\footnotetext{
${ }^{2}$ Most of our research participants were Senegalese men who had sex and/or romances with men (the situation of the few women among our research participants is beyond the scope of this paper). They used a range of terms to define their sexual practices and gender identity when speaking among them. When addressing foreigners, they often had recourse to the label 'gay' ('homosexuel' in French, which does not have the derogatory meaning that the word 'homosexual' has in English), which we therefore retained for this article. We use other appellations in accordance with other research participants' own expressions, such as 'men who have sex with men (MSM)' in the context of Senegalese and Mauritanian NGOs, 'LGBT' in the context of the UNHCR, etc. We use 'queer' as a conceptual term in conversation with queer migration scholarship, as will be detailed in the theoretical section.

${ }^{3}$ The total number of UNHCR 'beneficiaries' (asylum seekers and refugees) in Mauritania exceeds 2000, according to their office in Nouakchott (Interview with protection officer, February 15, 2018).
} 
we perceived at first to be a paradox. On the one hand, as West African gay men displaced in a country which criminalises homosexuality, they are supposed to receive special protection and are eligible to resettlement to the Global North on the ground of their sexual orientation; furthermore, gay men have become a priority in global policies against HIV. On the other hand, their living conditions including sexual health worsened since they left their country of origin. Departing from this paradox and its apparently lethal consequences, we question this programme for gay West Africans as a site of queer necropolitics - that is to say the politics of killing and letting live (Haritaworn et al., 2014; Mbembe, 2003) - of asylum. The following section will detail the methods and data on which reflections presented in this paper are based, before presenting the theoretical framework on which the analysis rests.

\section{Methods}

We, the authors of this paper, conducted three exploratory field visits in Nouakchott between 2018 and 2019. In February 2018 a first fieldwork was carried out by one of the authors (political scientist) in the frame of a doctoral project ${ }^{4}$ on LGBT resettlement from West Africa. It consisted of ten individual semi-directed interviews lasting from one to three hours with Senegalese men (and one woman) aged 20 to 35 years old residing in Nouakchott who identified as gay. These took place at their homes and were conducted in French and Wolof without the assistance of a translator. Four group discussions of three to four hours each were also conducted (two at the occasions of community lunches organised by representatives of Senegalese refugees in Nouakchott in the homes where they worked as domestic help and two group discussions in cafés).

\footnotetext{
${ }^{4}$ The first round of fieldwork was carried out as part of a doctoral thesis funded by the Max Planck Institute for Social Anthropology.
} 
Semi-directed interviews were also conducted with institutional actors: the representative of a Mauritanian NGO carrying out activities in support of gay men with HIV; the doctor in charge of the HIV treatment centre in Nouakchott; a social worker for the Mauritanian NGO implementing partner of the UNHCR; a protection officer of the Mauritanian UNHCR office (interview over the phone); a senior officer in the Mauritanian office of the International Organization for Migration (IOM).

In June 2018 and May-June 2019, surveys ${ }^{5}$ were carried out in Nouakchott by two anthropologists and a leader of a Senegalese LGBT organisation based in Dakar. Semi-structured interviews lasting between one and four hours were conducted in French, Wolof and Hassanya with: 20 Senegalese gay men, aged between 25 and 60, residing in Nouakchott as refugees, asylum seekers or rejected asylum seekers; three members of an LGBT organisation in Nouakchott; two employees of the UNHCR; three members of a Mauritanian NGO which carries out activities in support of Mauritanian and foreign gay men; five health professionals and social actors at the HIV treatment centre in Nouakchott; a community mediator in charge of the social support for Senegalese gay men; five organisation members of the network of people living with HIV organisations in Mauritania; and one person in charge of the national HIV/AIDS programme in Mauritania. We met most of these interview partners two times in June 2018 and May-June 2019. The interviews were complemented by observations at the organisations' headquarters, at the HIV treatment centre in Nouakchott and in bars and restaurants frequented by gay men.

Interviews with refugees and asylum-seekers were sometimes held in public places, such as cafés, but most often, for the sake of discretion, at their domicile or in an apartment we rented for this occasion. The meetings took place in a climate of trust because we came recommended by long-

\footnotetext{
${ }^{5}$ Supported by the ANRS site in Senegal and the IRD; one of them was also funded by the SCAC/Ambassade de France in Senegal. We thank Khaly Diaw for his participation in the research in Dakar.
} 
term informants based in Dakar or because they already knew one of us as the leader of a Senegalese LGBT organisation. People were often very eager to express themselves, to tell their stories, and some interviews lasted several hours. Bearing in mind ethical questions relative to conducting research with vulnerable people and particularly with refugees (Krause, 2017; Lammers, 2007; Menetrier, forthcoming), we have decided to compensate transportation and food costs induced by the interviews. When faced with requests for long-term assistance, we were careful not to make promises we could not keep, while informing our research participants that one of us (Djamil Bangoura) was planning to develop a programme to support Senegalese gay refugees in Nouakchott.

Interviews with health professionals took place at the hospital, several days in a row. We took advantage of the waiting time before appointments, where we sat on the benches with the patients to exchange and observe their movements. Meetings with organisations, NGOs and institutions took place on their premises. The welcome was generally very cordial, because coming from Senegal, we were recommended by common acquaintances in the medical and organisational environment. Institutional actors of the asylum system, such as the UNHCR, were more reticent to speak to us, especially during our research stay in May-June 2019. It might be due to the imminent resettlement of a group of refugees at that time, which UNHCR employees were anxious to keep discrete. Notes were taken throughout the three research trips in the form of fieldwork diaries and interviews were recorded (when agreed by our interlocutors), translated, transcribed, and subjected to systematic thematic cross-analysis.

\section{Queer necropolitics}


Certain populations whose fate is normally of minor interest to policy makers have experienced better political treatment due to their HIV infection and its associated health narrative. Didier Fassin calls this phenomenon 'bio-legitimacy' (2000, p. 105). In various national contexts, gay men began to receive benevolent attention once the specificity of their exposure to HIV was identified. When ART was made available in some African countries, this phenomenon became particularly visible. People undergoing treatment attained a different status with special rights and duties, following a principle Vinh-Kim Nguyen calls 'therapeutic citizenship' (2005). But when trying to understand the lives and deaths of the Senegalese gay asylum seekers in Nouakchott, this analytical framework appears insufficient.

In forced migration studies, the concept of 'biopolitics' is often used. Introduced by Michel Foucault in 1976, it describes a transformation in the state's exercise of power in the late eighteenth and early nineteenth centuries. A period dominated by sovereignty, or the 'right to take life or let live', was followed by the emergence of 'biopower' or a mode of government based upon the 'right to make live and to let die' (Foucault, 2003 [1997]). In line with the notions of 'biopower' and 'biopolitics', Achille Mbembe proposed the notion of 'necropolitics', which emphasises the 'right to kill' characteristic of many contemporary public policies, 'to account for the various ways in which, in our contemporary world, weapons are deployed in the interest of maximum destruction of persons and the creation of death-worlds, new and unique forms of social existence in which vast populations are subjected to conditions of life conferring upon them the status of living dead' (Mbembe, 2003, p. 40).

Jasbir K. Puar first elaborated on this notion to formulate the concept of 'queer necropolitics', intended to 'keep taut the tension between biopolitics and necropolitics' (Puar, 2007, p. 35). This notion was later taken up by other authors (Haritaworn et al., 2014) to study 'unequal regimes of 
living and dying' (Luibhéid, 2008, p. 190) under which sexual and gender minorities suffer in particular. This literature, in mobilising the notion of 'queer necropolitics', deals not only with biological death but also with symbolic death or what some authors call 'slow death', referring to 'the physical wearing out of a population and the deterioration of people in that population that is very nearly a defining condition of their experience and historical existence' (Berlant, 2007, p. 754).

The notion of necropolitics has increasingly been taken up in the study of forced migrations. In this bourgeoning field two types of studies can be distinguished. The first are set in the Global North and approach queer necropolitics as an interdependence between the rights granted by host states to selected LGBT asylum seekers and the politics of 'rightful killing' these states exercise over populations in the Global South - for examples, Shakhsari (2014a) juxtaposes asylum for trans Iranians in North America and US interventions in Iran in the name of the 'war on terror'; Davies et al. (2017) analyse refugee camps at European borders as sites of EU's violence over non-EU citizens; Mose \& Wriedt (2015) make a similar argument based on the militarisation of EU borders. This framing of queer necropolitics of forced migration presupposes that host states are engaged in politics of homonationalism. This is not the monopoly of states of the Global North, as Ali H. Bhagat's showed through his work on queer necropolitics of forced migration in South Africa: because of its progressive constitution, the country attracts gay Africans who are then subjected to state-sponsored racist and heterosexist (urban) politics (Bhagat, 2018, 2020; see also Camminga, 2019). But most countries to which gay migrants are displaced are actually less ambiguous about their rejection of gay migrants. In Mauritania, the country of destination of gay Senegalese, the state practices and publicly displays heteronormative violence and refuses to acknowledge gay asylum seekers as potential citizens. We argue that in such cases the 'ultimate 
expression of sovereignty' to kill or 'let live' (Mbembe, 2003, p. 12) is not solely in the state's hands - which unambiguously rejects gay migrants as citizens - but is partly delegated to organisations which formulate promises over gay migrants' access to rights. In Mauritania it is the UNHCR to which gay Senegalese asylum seekers turn, hoping for resettlement to countries of the Global North. The UN agency's resettlement programme thus constitutes a buffer zone between the adverse conditions in which gay West Africans were used to navigate and the homonational resettlement states' selection criteria which they have to get acquainted with. In this article we frame the buffer zone, the time of uncertainty during which gay Senegalese asylum seekers try to appear vulnerable enough for resettlement as 'slow death'. Thereby we wish to contribute to a conceptualisation of necropolitics in forced migration as a system of classification failing to inform and care for aspiring refugees rather than a project of hegemonic resettlement states or of the UNHCR. By taking the angle of Senegalese gay asylum seekers' exposure to HIV, we place this work in continuity with colleagues' efforts to document the 'material conditions' (Bhagat, 2020, p. 363) of those who seek asylum on the ground of sexual orientation or gender identity and wait in the Global South for resettlement to the Global North (Saleh, 2020a, 2020b; Shakhsari, 2014b).

\section{Fleeing the Senegalese context}

For most of the 2000s, Senegal was considered exemplary for its research on HIV among gay men and health programmes targeting them. It was indeed the first African country to measure HIV prevalence in this population (Wade et al., 2005) and to conduct interventions. But at the end of the 2000s, the situation deteriorated significantly. 
Homosexuality is penalised in Senegal under Article 319, paragraph 3 of the Penal Code, stating that "whoever commits an indecent or unnatural act with an individual of the same sex will be punished by imprisonment of between one and five years and a fine of 100,000 to $1,500,000$ francs'. Barely used during the twentieth century, this law began to be observed and enforced much more in the late 2000s (Camara, 2007-2008).

The persecution of Senegalese gay men has a long and complex history which peaked in 2008 and 2009 in the context of two successive crises. In January 2008, Icône magazine published photos of a 'homosexual marriage'. Religious and political figures reacted very harshly in the following days and weeks, forcing many gay men to leave the country. In 2009, nine gay men involved in the fight against HIV were reported to the police, arrested in a private home and sentenced to eight years' imprisonment for 'criminal association'. Their sentence was cancelled a few months later as the result of international pressure and local mobilisations. These two events ushered in a period of recurring police crackdowns, popular stigmatisation and violence, the severity of which never decreased over the next decade (Broqua, forthcoming).

In Senegal, many gay men live in constant fear. Social homophobia places them at the margins of society and exposes them to violence and discrimination, including beatings and rape. When victims file a complaint, it is usually dismissed without further action. They are therefore reluctant to testify to these attacks. Within the family, rejection and stigmatisation often begin at an early age, as this interview abstract with one of our research participants well illustrates:

I lived in Senegal with my family. I've always felt attracted to boys. My mother loved me, she understood that I was gay. My older brothers beat me, the neighbours insulted me because I looked effeminate. When my parents died, my brothers wounded me with 
a knife, I had to run away. I started a small business, I wanted to work, not steal. My family came to tell the market that I was gay. People burned my stall, I lost my business, I fled to Nouakchott in 2012 (Omar, 31, refugee in Mauritania, May 30th 2019).

Many young gay men therefore flee their family homes. As a result, they find themselves in a very precarious situation, without a fixed home, housed in turn by friends and acquaintances (PNUD \& $\mathrm{HCDH}$, forthcoming), sometimes even by leaders of LGBT organisations in their private apartment. Often they take the decision to leave Senegal following the opportunity to be housed by acquaintances abroad, like this young Senegalese man told us:

I found the time to escape to Mali after I was beaten up in the middle of the street in Mbour. So I went straight to Mali to a friend. But then things got tough over there so I talked to another friend who lived here in Nouakchott and he asked me to come here. He is a Senegalese who is also gay and he could host me because he was living with other gays (Amadou, refugee in Mauritania for 4 years, February 13th 2018).

This is how many fled Senegal to Morocco, Tunisia, Côte d'Ivoire, Mali, and more recently The Gambia or, as in the case we are interested here, Mauritania.

\section{The enduring call for resettlement}


The migration of Senegalese gay men to Mauritania is not a new phenomenon. Some of our research participants left more than 20 years ago in the hope of finding work or putting distance between them and their families to avoid disclosing their sexual orientation. But their number has significantly increased since the late 2000s, together with the rise of controversies, arrests and violent attacks in Senegal. Their hopes have also evolved, as more of them discover the possibility to claim asylum in Nouakchott and then be selected for 'resettlement' to Europe or North America by the UNHCR.

Refugee resettlement is the process by which some refugees depart their first country of asylum for a third which offers them protection on a permanent basis (Newland, 2002). Since the creation of the UNHCR at the beginning of the Cold War, its preference has alternated between resettlement and other 'durable solutions' depending on pressure from donor states in the Global North and host states' capacity in the Global South (Chimni, 2004; Garnier, 2016). Notwithstanding the UN agency's 'post-2006 accountability commitment' (Jacobsen \& Sandvik, 2016, p. 9-10), where refugee resettlement is concerned, 'accountability mechanisms still exclude the participation of refugees' (Garnier, 2016, p. 68). As UNHCR resettlement agents always remind social scientists when starting an interview, 'First one must realise that resettlement is not a right.' On the agency's website, in its answer to the question 'What is refugee resettlement?', the UNHCR puts the resettlement country ('third state') and the first country of asylum in the foreground, omitting its own role in the selection process (UNHCR, 2016). This omission is representative of the polymorphous and thus often unclear position of the UNHCR between resettlement aspirants, the first country of asylum and the resettlement state.

In most cases, it is the state which, either alone or together with the UNHCR, runs Refugee Status Determination (RSD) procedures and thus sovereignly decides whether or not to recognise 
individual asylum seekers as refugees. Notwithstanding the UNHCR's effort to convince governments to develop their own national procedures, some countries remain reluctant to do so, such as in Mauritania (Fresia \& von Känel, 2016, p. 104). In such cases, it is UNHCR staff (part of the protection unit) who conducts the RSD procedure, decides what statuses are awarded and submits only their final assessment to the national eligibility commission for approbation (to date, according to the UNHCR website, the agency has conducted RSD under its mandate in 50-60 countries and jointly with the governments of 20 countries).

In the case of Mauritania, such a commission was constituted in 2005 with financial and technical assistance from the UNHCR, but it was the latter that conducted RSD under its own mandate (ibid., p. 106). Anthropologist Andreas von Känel, who conducted fieldwork in the UNHCR office in 2009 , points to the protection office's constant work of negotiation to produce the impression that RSD stands outside of politics (ibid., p. 108). The UNHCR strove to anchor the refugee category ${ }^{6}$ in the Mauritanian institutional landscape, and training the national eligibility commission to conduct RSD according to UNHCR guidelines was one of the means deployed. Protection officers thus decided to submit only exemplary or 'solid' cases (with clear persecution grounds) for review by the national commission, which contributed to casting the agency's (and thus the commission's) mandate in a good light. But already in 2009, UNHCR eligibility officers were confronted with the dilemma that gay asylum seekers from Senegal continue to pose for them 10 years later, as we write these lines. Indeed, the Mauritanian Ministry of Justice warned the UNHCR that, in accordance with the criminalisation of homosexuality in the country, the national commission would not accord refugee status to gay claimants and would likely expel them (ibid., p. 109).

\footnotetext{
${ }^{6}$ As opposed to migrants who were suspected of crossing Mauritania to reach Europe.
} 
Although most of them constituted 'solid' cases in terms of proof of persecution, ${ }^{7}$ in order not to jeopardise its relationship with the host state, the protection unit decided not to refer these cases to the national commission, still awarding them refugee status under UNHCR mandate. Because they feared similar persecution in Mauritania as in their country of origin, UNHCR Mauritania would then try to resettle Senegalese gay men to a third country. The fact that resettlement remains the only 'durable solution' for Senegalese gay men once the protection office recognises them as refugees plays a significant role in the very decision whether to award them refugee status or not, as a UNHCR eligibility officer quoted by von Känel clearly expresses: 'If we want to accept a homosexual, it should really be an extremely strong case. Otherwise we will end up giving protection to half of all homosexuals in Senegal!' The officer said this after explicitly referring to the obligation to resettle 'them' because 'we can't leave them in Mauritania' (ibid., p. 109). This quote is very telling for the dilemma that the UNHCR is facing in Mauritania - and in other countries that have criminalised homosexuality (see Menetrier, 2019). The protection office is both judge and party to the asylum procedure. For the protection office, deciding to recognise asylum seekers as refugees under UNHCR mandate because of their sexual orientation amounts to a strain on the office's resources. Indeed, this decision would not only demand financial resources to cover the basic needs of these 'mandate' refugees during their time in Mauritania but also the human resources necessary to build these refugees' future resettlement cases as well as the diplomatic resources to convince third countries to accept them. Considering all these costs, added to the risk

\footnotetext{
${ }^{7}$ The UN agency first published a 'guidance note' in 2008 (UNHCR, 2008) followed by 'guidelines' (UNHCR, 2012) that include sexual and gender minorities among the populations 'of concern' to the UNHCR. In 2014-2015, 'almost two thirds of participating offices indicated having implemented reception or registration measures specifically targeting LGBTI persons of concern to UNHCR' (UNHCR, 2015, p. 3). In Senegal itself, the UNHCR country office receives requests from displaced gay men, notably from The Gambia (Menetrier, 2019), but Senegalese nationals are not eligible in their own country of origin.

Apart from UNHCR, various countries have also opened their asylum systems to sexual and gender minorities, for example in Europe (Fassin \& Salcedo, 2015; Giametta, 2017; Raboin, 2017) or North America (Murray, 2015). For a discussion of this opening, see OHCHR, 2011.
} 
of a potential conflict with the Mauritanian host state, UNHCR eligibility officers tend to award refugee status to Senegalese asylum seekers not on the sole ground of persecution based on their sexual orientation, but on the likeliness that they would later be chosen for resettlement by third countries.

Many of the Senegalese we met in Nouakchott in 2018-2019 must have had a 'strong case', since the UNHCR had granted them refugee status years before. Soon after, they were informed that the USA had agreed to resettle them. But after D. Trump was elected president, the USA drastically reduced the scope of its resettlement programmes (Kanno-Youngs \& Shear, 2019). The resettlement of the newly recognised Senegalese refugees in Nouakchott was paused. The UNHCR regional office of Oman (on which the country office of Nouakchott depends administratively) has since tried to convince other resettlement countries to accept these 'pending cases', so far without success. ${ }^{8}$ In the meantime, the UNHCR office in Nouakchott had to provide these 'mandate' refugees with basic (medical and alimentary) assistance, discretely enough in order to avoid provoking the Mauritanian state with this blunt circumvention of their sovereignty. Among the group of about 100 Senegalese gay men present in Nouakchott (according to our observations in 2018 and 2019), the aforementioned individuals whose resettlement to the USA has been postponed represent only one of a variety of situations we encountered. Some were waiting for a decision on their asylum claim (they were thus asylum seekers according to the UNHCR) while others had seen their applications rejected (they were thus no longer 'of concern' to the UNHCR). Despite this variety of profiles among Senegalese gay men living in Mauritania, what they had in common was the transience of their lives in Nouakchott, which they conceived of as transit time.

\footnotetext{
${ }^{8}$ Once refugees are engaged in a resettlement procedure with a third country, it is very difficult to remove these cases from the 'pipeline' to submit them to another resettlement country, as a UNHCR agent in Mauritania explained (February 2018).
} 
Even those who had arrived in the late 2000s and had only recently learned about the resettlement option now geared their efforts towards meeting what they imagined were the criteria of the asylum procedure.

In her article 'The queer time of death', Sima Shakhsari argues that Turkey, where Iranian queer and trans refugee applicants try to qualify for resettlement to the Global North, is an 'in-between zone of temporary refuge' where 'refugees live a slow death in the sluggish tempo of rights' (2014b, p.1000). The 'progressive time of rights' - the LGBT rights promise towards which Iranian asylum seekers must strive in their flight narratives during interviews with the UNHCR and representatives of resettlement countries - paradoxically comes to a halt during this transit time ruled by Turkish immigration law. The situation is very similar for gay Senegalese in Mauritania. They must appropriate refugee and LGBT rights discourses in order to convince asylum agents of their urgent need to be resettled to the Global North, while simultaneously developing protection strategies in the absence of such rights. By purposely postponing the award of refugee statuses to gay Senegalese asylum seekers to a moment when a 'resettlement solution' seems imminent and by failing to inform recognised refugees on the temporalities and chances of their resettlement applications, the UNHCR maintains them in an 'in-between state' during which the agency delegates its responsibility to 'let live' to local organisations and the Senegalese 'community' ${ }^{\prime}$ itself.

\section{'Pending cases' or a life of waiting in Mauritania}

\footnotetext{
9 The term is used by the UNHCR, their partner organisations and representatives of Senegalese refugees to the UNHCR.
} 
Mauritania, an Islamic republic, is often listed as one of four African countries with the death penalty for homosexuality, which is punishable under Sharia law as well as Article 308 of the Penal Code: 'Any adult Muslim who commits an indecent or unnatural act with an individual of the same sex shall be punished by death by public stoning.' In practice, the death penalty has not been applied in Mauritania since 1987.

According to our Senegalese research participants, homosexuality, although theoretically penalised, is relatively tolerated in Mauritania, provided it is discreet. Some Senegalese thus reported that their current living conditions were better than those they had left behind. As in Senegal (Broqua, 2017), góor-jigéen is a category which has experienced a resignification phenomenon (from 'man-woman' to gay) in Mauritania. But unlike in Senegal, where the celebrated figure of the worldly góor-jigéen has almost disappeared, it somehow remains tolerated in Mauritania (Lesourd, 2008, 2010).

Many Mauritanian Moorish families have a strong attachment to the reputation of the 'clan', which they would defend under all circumstances. The disclosure of homosexuality thus leads to isolation within the family rather than expulsion from the home, as is the case in Senegal. If the 'disclosed' gay man can remain discrete so as to safeguard the honour of his family, the latter provides relative tolerance. In case of illness, families care for infected relatives.

As long as people don't openly disclose their sexual orientation, they can live a carefree life. The family protects each member, no matter what they may do. The dishonour of one member reflects on the whole tribe. We prefer to hide the gay members, defend them if need be. I know a young man, when he was sick, the whole family took care of him. But they demanded that he be discreet, that no one could know 
who he was (Head of a Mauritanian NGO that carries out activities in support of MSM, May 28th 2019).

However, it is necessary to contextualise these remarks, as some Mauritanian gay men reported assaults and thefts by youth gangs, harassment by police forces and dismissed complaints. Among the Senegalese gay men we met in Nouakchott, some had been there for a few months, others for several years. For some it was their first stay outside of Senegal, while others had also stayed in The Gambia or Morocco, also seeking refugee status. They chose Mauritania for its proximity, the porosity of its border and the existence of a network of Senegalese gay men, which nourish its reputation as a favourable destination for aspiring refugees.

Newcomers to Nouakchott are hosted by Senegalese friends who they contact in advance via social networks. While these accommodations and the pooling of scarce savings may be enough for a few weeks, newcomers must quickly find a more sustainable solution as their transit period begins to drag on.

Two characteristics specific to the Senegalese gay group in Mauritania are essential to understand the precariousness in which they remain mired in Nouakchott.

The first is related to the visibility of their sexual orientation or gender identity. The testimonies collected reveal violent attacks by gangs of young Mauritanians targeting Senegalese people whose clothing diverges from the image of pious masculinity that is generally cultivated in the streets of Nouakchott. Within the Senegalese gay community, men accuse each other of bad 'behaviour' - public conduct that does not conform to what is expected of a man in Mauritania and 'vulgar' clothing - feminine, tight or sequined clothing worn in public. The 'elders' who have been in exile for a longer time interpret this conduct as the expression of young people's feeling 
of liberation in Nouakchott, far from their hometowns and the eyes of their relatives. These attitudes also provoke the disapproval and concern of Mauritanian gay men, fearing that the discretion that had hitherto allowed them to live in relative tranquillity might be disturbed.

If you're too effeminate, you're in trouble. Some Senegalese wear make-up, put on veils, walk like women. We can do that, but in private, when we're with friends. If we go out, we go back to the 'normal man'. Them, they get us into trouble (Mauritanian organisation leader, June 7th 2019).

The second is related to the visibility of their status as foreigners. Mauritania is home to the Bambara, Haalpulaar, Soninke and Wolof populations, who call themselves 'Negro-Mauritanians' in distinction to the 'Moors', who call themselves baydhân in Arabic, referring to the colour white (Antil \& Lesourd, 2012). International media and human rights organisations regularly denounce Mauritania as one of the countries where slavery practices persist. These practices are based on the reproduction of a strict hierarchical order between 'Moors' and 'Negro-Mauritanians', but also within the group of 'Negro-Mauritanians' itself (Leservoisier, 2008). Since its independence, Mauritania has been politically torn between North Africa and West Africa, and the 'NegroMauritanian' population has continuously denounced the expulsions (Fresia, 2009) and racist violence it suffered before and after independence. Settling in Nouakchott, Senegalese gay men have thus come to a city that is socially and spatially fragmented along ethnic lines.

Paradoxically, their status as asylum seekers or refugees does not make Senegalese gay men immune to this double visibility but exposes them more. Indeed, poorly paid police officers systematically control Senegalese passers-by and arbitrarily apply fines to those who do not carry 
Mauritanian identity documents. The Senegalese first believed that the refugee card issued by the UNHCR was a legal proof of residence, protecting them in the event of arrest. But Mauritanian police, used to seeing this card carried by nationals of countries torn by armed conflicts, were surprised to see it brandished by single men coming from a country at peace. The police then made the link between Senegalese card holders and the alleged 'acts against nature' some of them were accused of. The Senegalese refugee card has in this way become a 'gay stamp' in Nouakchott, as one young man from Mbour ironically called it.

If they know how to cook, clean and remain discreet about their sexual orientation and gender identity, some Senegalese asylum seekers or refugees can be employed as domestic servants by a Mauritanian family. These jobs are constraining and poorly paid but offer a level of security by providing a hide-out from the police and public gaze.

On the streets of Nouakchott and due to their dual visibility, Senegalese gay men are often solicited by Moorish men who offer them money for sex (often unprotected). Many of our Senegalese research participants mentioned that they occasionally had recourse to transactional sex to sustain their needs. The activity is risky, as sex workers are driven in cars by clients to areas far from the city centre, where some are raped, beaten and sometimes even left for dead.

I worked as a boy in a Moorish family, I was a cook, but I was denounced, and I was fired. To live, I go to meeting places in the evenings. One night, a car stopped, I was taken by force to the beach, I was raped by seven men. Two of them were policemen. Then I walked home, with the car behind me. For weeks I was sick, traumatised, I didn't want to go out (Ibrahima, 27, asylum seeker in Nouakchott for seven years, May 30th 2019). 
Another remunerated but illegal activity for which Senegalese gay men can easily be recruited is to assist Mauritanian women in their transactional sex business. Gay Senegalese are considered to be ideal middle men to look for male clients on the city's streets and guide them to the tenant's house. This activity makes Senegalese gay men very visible to the public and the police and extremely dependent on the tenant's will to protect them. Senegalese refugees who practiced transactional sex or worked for brothel tenants have been arrested in the past without beneficiating from UNHCR protection.

We have an anti-refoulement lawyer to help with cases of deportation or arrests. But if it was the refugee's fault, we cannot do anything (Olivia, UNHCR employee, February 15th 2018).

The UNHCR office in Mauritania is thus bound to Mauritanian domestic law and cannot protect refugees accused of violating this law. As black gays, Senegalese asylum seekers in Mauritania are particularly exposed to the ethnic and heterosexist politics of the state carried out among others by poorly paid policemen. Similarly to what Bhagat noted in the case of queer African migrants, gay Senegalese in Mauritania are 'simultaneously 'too African' due to their nationality and 'unAfrican' due to their sexual and/or gender identity' (Bhagat, 2020, p. 362). If they are prepared to face necropolitics of the state, gay Senegalese refugees we talked to were surprised that their refugee card and the UN agency which awarded it could not intervene to protect them.

Precarious employment and housing situations as well as xenophobia are often the lot of populations in exile. People in exile can typically rely on a strong network of compatriots who 
migrated to Mauritania before them. Similarly, as previously touched upon, Moorish gay men who face homophobia benefit from relatively good family support. On the contrary, the Senegalese gay men we met in Nouakchott are excluded from circles of Senegalese nationals because of their homosexuality and are also, for the most part, cut off from familial ties of solidarity (which, already compromised while in Senegal, were often the reason for their departure).

In Nouakchott, there is no united and supportive Senegalese gay community to be found. One could rather speak of a network of friends scattered throughout the city, fused by their common asylum processes. Uncertainty pertaining to the attainment of refugee status and resettlement weakens the groups that do form. Indeed, the opacity of selection criteria (especially for resettlement) sows discord among asylum seekers, who know that only a few will be chosen.

I wonder if I'll be able to leave. It makes me anxious. Some people got the card after me, they've already left. A friend who was already there when I arrived is still waiting. B. lasted six years before he left (Bilal, 35, a refugee for five years, awaiting resettlement, May 30th 2019).

Many of the interviews we conducted with gay Senegalese revealed an atmosphere of competition and suspicion within the 'community'. They feared that a compatriot would discredit them during an individual interview with the UNHCR by telling their secrets. Senegalese gay men are therefore reluctant to share details of their 'previous' lives that could compromise the story of flight they tell UNHCR agents, such as a past heterosexual marriage (Menetrier \& Lawrance, forthcoming), a recent trip to Senegal or the contraction of a contagious disease. 
This last point remains a grey area for most Senegalese gay men in Nouakchott. In previous years, they have seen some of their friends relocated to the United States, Canada or Sweden, with a medical testing phase conducted by the International Organization for Migration (IOM) always preceding their departure. Some diseases, such as tuberculosis, were a barrier at first, while others, such as HIV, seemed to be an asset in the asylum process, given the proportion of HIV-positive friends resettled before them by the UNHCR.

\section{Accessing ART and health care in Nouakchott}

Mirroring the high prevalence of HIV infection among gay men in Senegal (CNLS, 2018), some of the refugees were HIV-positive before entering Mauritania. Those who were aware of their infection were for the most part treated with ART before leaving, with follow-up visits at a treatment site in Dakar. Arriving in Nouakchott with one or two boxes of medication, they inevitably had to turn to the Mauritanian health system to restock their supplies of medication. Antiretroviral treatment requires daily medication to maintain the immune system and prevent potentially serious and life-threatening illnesses. Taking this medication regularly is therefore a vital issue, and repeated interruptions can have serious consequences: on the one hand because of the immediate risk of illness and death, and on the other because multiple interruptions are linked to the development of viral resistance and thus increase the likelihood of treatment failures. Such failures are currently a major public health problem in Africa (Laborde-Balen et al., 2018).

Taking care of ART patients therefore usually includes biomedical monitoring and support for what is referred to as their 'therapeutic adherence', i.e. taking their drugs in accordance with the medical prescription and without interruptions. This support is provided by a psychosocial team 
working in collaboration with the medical team. This common model for national HIV/AIDS programmes is also the one in force in Mauritania, though with less success where Senegalese in exile are concerned.

In Nouakchott, at the time of the survey (2018-2019), there was only one functional HIV care site, the Outpatient Treatment Centre (Centre de traitement ambulatoire, CTA), located within the National Hospital Centre. Like in Senegal, ART and follow-up biological tests are free of charge, as they are subsidised by the national HIV/AIDS programme. Senegalese have access to them because free HIV medical care is conditioned by place of residence (in Mauritania), not by nationality. Refugees and asylum seekers alike can therefore benefit from it, but only the former are entitled to reimbursement for all health care expenses by the UNHCR, including those related to other diseases.

Community meals and discussion groups have been held regularly at the CTA, despite an interruption in 2019. They are accompanied by a small allowance as reimbursement for transport and are therefore very popular. Due to a lack of sufficient funding, they only involve a limited number of participants, who are selected by social workers. According to our interviewees involved as social workers, the main criteria for inclusion are indigence and ethnic diversity. However, in a multicultural society where everyone fears being accused of bias in favour of his or her own ethnic group, the selection process is controversial. The Senegalese, for their part, believe that priority is given to Mauritanians at the expense of foreigners. In addition, in 2018, Senegalese gay men were excluded from these activities because of behaviour considered 'disruptive' and 'provocative'.

While a large number of HIV-positive Senegalese gay men are regularly monitored at the CTA, others have more chaotic treatment pathways. Some arrive after months of interrupted treatment 
because they were unaware of where to go and did not dare to ask their friends for information for fear of disclosing their HIV status. Others, diagnosed HIV-positive in Mauritania, do not return after testing or disappear after a certain period of treatment. According to the doctor, financial difficulties in paying for transport to the hospital as well as the fear of stigmatisation partly explain these defections. Indeed, HIV infection is at least as stigmatised in Mauritania as it is in Senegal. Although the doctor responsible for care at the CTA is much appreciated by the Senegalese gay men for speaking Wolof and proposing appointments outside of peak hours for greater discretion, patients prefer to avoid being seen near the building, which is commonly associated with HIV. We have observed that many patients hide their faces during consultations and prefer waiting inside the building rather than on the benches outside, where they are exposed to the gaze of passers-by. People say that they avoid using terms referring to HIV in front of others and use codes such as 'the big house' for the CTA and 'peanuts' for ART when talking to other infected people. HIV status is not openly shared within the Senegalese gay 'community' in Nouakchott. Infected people hide their disease by using various strategies: medicines are taken out of the packaging, boxes are thrown away, labels are torn off, bottles are hidden at the bottom of a suitcase and medicines are taken discreetly.

I've been in a serious relationship for three years. I'm staying with him, we live together. He's 50 years old, he's been here a long time, he works, he earns a living. He doesn't know my status. When I come back from the hospital, I throw the box away, I put the pills in a Vitamin $\mathrm{C}$ box, I tell him that the doctor told me I need to take vitamins. I'm afraid he'll leave me if I tell him. Here we hide from each other, if they 
know you're HIV-positive, they'll stigmatise you (Boubacar, 31, Senegalese asylum seeker, HIV-positive since 2009, May 30th 2019).

These strategies, common among people living with HIV (Sow \& Desclaux, 2002), are difficult to implement in a context of communal life, shared housing and frequent and sudden moves or homelessness, and lead to irregular intake and even interruptions in treatment. These are typical barriers to access to care and can be seen in other precarious contexts (Taverne et al., 2014) where the most vulnerable also are those with less power to access health care (Ribot \& Peluso, 2003). This being said, the state of waiting in which gay Senegalese find themselves in Nouakchott adds another layer to their condition of 'living dead'. The interminable wait for refugee status and the hope for an imminent departure is incompatible with the long-term energy necessary to comply with the fixed daily times of ART treatment. We observed that many sink into a form of depression, voluntarily abandon treatment, experience resurgences of illness and sometimes die of it, in Nouakchott or upon return to Dakar. Several cases of death have left their mark on people's minds. We have reconstructed their journeys by cross-referencing the accounts made by friends of the deceased during interviews and by health professionals who cared for them.

M. died in 2017. He had arrived in Nouakchott seven years earlier to flee persecution in Senegal. He had been granted refugee status after a few years and was awaiting resettlement. He is reported to have been generously involved in the social life of the Senegalese community. He had started ART in Senegal and continued his treatment at the CTA in Nouakchott. In exile he experienced a succession of setbacks - imprisonment, assaults and the loss of his home - and was living in a state of considerable socio-economic precariousness. In recent years, he had been staying with friends who did not know his HIV status. He took his medication in hiding, always feared that his 
boxes would be uncovered, no longer dared to go to the CTA for fear of being seen and finally gave up his treatment. He fell ill. His friends helped as they could, but he refused to return to Senegal because he was hoping for imminent resettlement. He ultimately died shortly before his scheduled departure.

The case of B., who died in 2018 at the age of 25, shortly before one of our missions in Nouakchott, came up in almost all of the interviews we conducted. He was receiving ART and had problems with compliance. He contracted tuberculosis, which required hospitalisation. He died during treatment. It was a traumatic event for all those who mobilised to help him. In cases of severe illness, Senegalese tend to return home. It is believed that caring for a seriously ill person is the material and financial responsibility of the family and that one should die in one's birth country. B., however, refused to repatriate. As his family had rejected him, he knew he would not receive any help or affection at home in Senegal. As a refugee card holder, he also hoped to benefit from rapid resettlement due to his state of health.

Deaths of Senegalese gay men in Nouakchott have thus been precipitated by a range of psychological and social factors: economic precariousness, the difficulty of managing ART and lassitude and depression in an 'in-between state' contributed to their distress, the consequent abandonment of treatment and eventually death. While most had cut ties with their biological families, local organisations and mutual aid within the community of exile showed its limits and did apparently not suffice as a bulwark against the 'slow death' to which gay asylum seekers and refugees are subjected in transit in Nouakchott.

\section{UNHCR's relationship to HIV}


The issue of HIV is at the heart of the UNHCR's engagement with Senegalese gay men. The fact that a large proportion of them are infected with HIV is taken into account by the UN agency in two ways: on the one hand, the health costs of HIV-positive Senegalese are fully covered when they hold a refugee card (unlike asylum seekers); on the other hand, they seem to be prioritised for resettlement.

Paradoxically, HIV status thus represents an opportunity. Both Senegalese asylum seekers and health professionals we talked to gave us the same information: the Senegalese gay men who were resettled to the United States just before our second mission in 2018 were HIV-positive. Some informants even claim that all Senegalese resettled to date were HIV-positive. According to one of our research participants (an asylum seeker), this has become the first criterion in the UNHCR's selection for resettlement.

All Senegalese gay men we interviewed in Nouakchott shared the opinion that HIV-positive status is a - if not mandatory, at least favourable - condition for resettlement. This observation annoys those who are seronegative, as illustrated by the disappointment of a young Senegalese man to whom the CTA's doctor reported a negative result. The temptation to contaminate oneself in order to increase one's chances of travel logically leads to voluntary exposures to HIV, as observed in France among migrants seeking a residency permit (Ticktin, 2006, 2011).

The UNHCR is certainly concerned about the issue of HIV among asylum seekers. However, at the time of application and until the card is issued, there is no specific information to refer people to HIV testing and care sites. This is despite the fact that there are frequent interruptions of ART among newcomers and rarely spontaneous screenings. Moreover, persons who do not enjoy refugee status do not have access to medical care outside the ART of the national programme. 
The UNHCR is thus placed in a double bind: on the one hand, it ensures the health of HIV-positive Senegalese with a protective refugee status and favours their resettlement; on the other hand, it withholds this very information both to preserve the privacy of resettled persons and above all to avoid causing voluntary exposure to HIV, well aware that this is an unwanted consequence of its selection process.

\section{The asylum system: protective or deadly?}

A seminal 2004 article on 'sexual migration' - referring to international resettlement on the basis of sexual orientation and gender identity - highlighted the scarcity of work linking this theme to (sexual) health (Carrillo, 2004). This is still true today, with the notable exception of a couple of studies focusing on the sexual health of those, within diaspora, who migrated for reasons related to their sexual orientation - Carrillo (2017) on Mexican 'sexual migrants' in the USA; Adam \& Rangel (2017) on 'homosexual Latino' men in Canada; Yue (2008) on 'homosexual Asians' in Australia. But this body of work invariably focuses on nationals from the Global South who have migrated to countries of the Global North. Sexual health is thus approached departing from the assumption of a discrepancy between the sexual culture of the country of origin and the host country. These studies rarely consider the living conditions of immigrants in their countries of origin, the cultural systems prevailing there and the practices and ideas of destination countries to which aspiring emigrants are exposed prior to migrating. By shifting the focus to 'sexual migration' within the region of origin, in this case West Africa, we showed that 'sexual migration' and sexual health are intimately linked even in the case of migration to a neighbouring country, where sexual culture and health infrastructures are, at first glance, similar. Studies on sexual health 
of 'sexual migrants' in the Global North have assumed that special vulnerabilities result from migration in terms of transmission and acquisition of STDs (Carrillo, 2004, p. 66). We showed that it is true for gay Senegalese in Mauritania as well. However, the explanation does not lie in them being uprooted and their patterns of sexual behaviour 'destabilised by contact with new sexual cultures' (ibid.). We argue that it is rather the 'in-between state' of uncertainty in which the asylum system retains them which contribute to their greater exposure to HIV.

In Nouakchott, as elsewhere, the UNHCR only grants refugee status to Senegalese gay men who can prove that they fled their country because of persecution due to their sexual orientation. This status, however, does not guarantee that they can travel North. Departures mostly depend on the resettlement quotas of host countries.

Refugee status entitles its holder to a card. In addition to the hope for resettlement, it provides various advantages in Mauritania: legal residence in the country, relative protection in the event of arrest (through the UNHCR's lawyers), occasional food distributions and medical care. On the other hand, for those who have applied but have not (or not yet) obtained this status, this protection does not apply.

As mentioned above, there is great diversity among the situations of those who apply to the UNHCR for asylum. Nevertheless, most of them settle into a life of anticipation, each new departure arousing both the disappointment of not being among the chosen ones and the hope of being part of the next 'wave'. Senegalese gay men in Nouakchott are therefore living anxiously, waiting for months or even years - sometimes more than ten years. For them, the city becomes an intermediate place of transit (Streiff-Fénart \& Poutignat, 2006), where they remain, in a sense, under house arrest. Indeed, once the application has been made to the UNHCR or, a fortiori, when 
the refugee card is obtained, claimants are in theory no longer entitled to leave the city and must be reachable at any time.

Moreover, a large proportion of those who were definitively rejected by the UNHCR remains in Mauritania. They are therefore no longer really in 'transit', but in 'post-transit' situations (Choplin, 2010). No longer forced to reside in Nouakchott, some of them settle in Nouadhibou, a port city where life is considered less austere and where opportunities for small-scale trade and sex work are more numerous. However, even rejected applicants do not always turn the page on their UNHCR request, ${ }^{10}$ stretching out this liminal state of anticipation.

Whether they are awaiting a response from the UNHCR, awaiting resettlement or permanently rejected, all lead a life conditioned by the asylum system, UNHCR policy and resettlement countries. The UNHCR seeks to ensure the safety and health of the sole refugee beneficiaries, providing them with a variety of benefits. At the same time, refugees and asylum seekers alike are exposed to various risks due to their prolonged presence in the city.

The lack of a residence permit makes it difficult to find a job and increases precariousness. Some of the people we met were sex workers at risk of exposure to HIV (especially since the possession of condoms constitutes a risk of arrest in the event of police control). Ironically, refugee cards indirectly betray their Senegalese holders' homosexuality, making them vulnerable to arbitrary treatment by police. In case of arrests, UNHCR officials say they cannot intervene in favour of their beneficiaries, as sex work is a criminal offense. In this regard, both the Mauritanian state and the UNHCR reinforce the biopolitics of 'letting die', which de facto affects gay asylum seekers the most.

\footnotetext{
${ }^{10}$ In some cases, when new evidence on one's past or present situation can be presented, one can request that the file be reopened.
} 
In addition, the impossibility of 'local integration' for Senegalese refugees in Nouakchott disqualifies it as a 'durable solution' for the UNHCR and thus opens the prospect of resettlement to a third country (UNHCR, 2007). Some Senegalese gay men deliberately put themselves at risk in pursuit of bodily evidence (Fassin \& d'Halluin, 2005) that will testify to the violence they suffer. Since HIV status is known as a selection criterion for resettlement to a third country, some people voluntarily try to get infected, which could be interpreted as an attempt to become 'bio-legitimate' in the eyes of the UNHCR. We could not find any preventive intervention to address this risk. The decline in Global Fund funding and the difficulties of government disbursement in recent years have slowed the CTA's social and community support activities. In addition, there exist few formal links between the UNHCR and local HIV organisations.

For some, prison adds to those risks. A recent news item offers an instructive example of the dangers faced by Senegalese gay men in Nouakchott. In January 2020, eight men, including several Senegalese, were sentenced to two years in prison for 'committing indecent acts' and 'inciting debauchery' after a video showing them 'dancing like women' was posted on social networks and in the media (Human Rights Watch, 2020). Among those arrested were refugees, who have been sentenced to expulsion.

\section{Conclusion: Adverse effects inherent to the asylum system}

Like migrants of sub-Saharan origin in France (Musso, 2012), few Senegalese gay men in Nouakchott can benefit from the additional 'therapeutic citizenship' granted by their status as HIVpositive persons on ART. They are rather subjected to a 'necropolitics' which exposes them to increased health risks, even if the UNHCR's policies towards Senegalese gay men in Mauritania 
differ from the most radical state-led forms of 'letting die'. The exposure of refugees to the risk of death and to death itself by UNHCR politics should not be thought of in terms of intentionality but in terms of structural effects.

Indeed, the official objective of resettlement is to preserve life by extracting those who are considered most vulnerable out of West Africa and opening Northern countries' doors to them. However, some of the asylum seekers who settle in Nouakchott seeking the UNHCR's protection find themselves in very poor health, in certain cases leading to death. Although the preservation of life is an official objective, and although one cannot speak of inaction in the strict sense of the term, one must nevertheless recognise the deadly effects of the system. Despite the UNHCR's stated willingness to take into account the HIV status of refugees and to fight HIV within this group, the asylum system is proving deadly. It produces undesirable effects which, although unintended and contrary to its stated objectives, are inherent to the system.

All national asylum systems open to sexual minority applications expect applicants to attest to the danger and precariousness they have fled. The UNHCR's resettlement programme operates according to the same mechanism. Yet unlike those seeking asylum in the Global North, who are often assisted by local human rights NGOs, our Senegalese research participants still reside in their region of origin while awaiting resettlement. To the UNHCR and resettlement countries, they must therefore attest not only to the danger and precariousness they fled in their country of origin but also to the dangers they currently face in their transit country. This system has deleterious effects, which the UNHCR itself acknowledges in encouraging the departure of people who report violence or serious problems (including health-related ones) encountered in transit.

In this paper we chose to extend the classic understanding of necropolitics as the expression of 'states' right to kill' to international organisations (IOs) such as the UNHCR. If certain public 
policies can directly be ascribed to governments' - of states of the Global North but also of the Global South - intentional necropolitics, it is less evident for IOs-led policies. Through the study of the resettlement programme for LGBT asylum seekers in Nouakchott, we showed that a deathworld could emerge as a result of UNHCR's practices and techniques despite the UN agency's declared goal of protecting LGBT lives.

This paper does not intend to amalgamate the situation of Senegalese gay men in Nouakchott with cases where UNHCR policies may have led quite directly to mass deaths (Agier, 2006). Not all deaths among sexual or gender minorities in Nouakchott can be attributed to UNHCR policies, since they also occur among those who are neither asylum seekers nor refugees. Yet the UNHCR is not only failing to prevent deaths among refugees and applicants 'under its mandate', but partly contributes to their 'slow death' by failing to inform and accompany its 'beneficiaries'. Counter to its objectives, the asylum system forces individuals who seek its protection to a level of liminality that exposes them to significant, sometimes fatal, health and social risks.

\section{References}

Adam, B. D., \& Rangel, J. C. (2017). Migration and sexual health among gay Latino migrants to Canada. The Canadian Journal of Sociology / Cahiers canadiens de sociologie, 42(4), 403-424.

Agier, M. (2006). Protéger les sans-État ou contrôler les indésirables: où en est le HCR? Politique africaine, 103, 101-105.

Antil, A., \& Lesourd, C. (2012). Une hirondelle ne fait pas le printemps: grammaire des mobilisations sociales et politiques et retour de la question négro-mauritanienne. L'Année du Maghreb, VIII, 407-429. 
Berlant, L. (2007). Slow death (sovereignty, obesity, lateral agency). Critical Inquiry, 33(4), 754780.

Bhagat, A. (2018). Forced (queer) migration and everyday violence: The geographies of life, death, and access in Cape Town. Geoforum, 89, 155-163.

Bhagat, A. H. (2020). Queer necropolitics of forced migration: Cyclical violence in the African context. Sexualities, 23(3), 361-375.

Broqua, C. (2017). Góor-jigéen: la resignification négative d'une catégorie entre genre et sexualité (Sénégal). Socio, 9, 163-183.

Broqua, C. (forthcoming). Homosexuality in francophone West Africa: The international context of local controversies. In D. Haider-Markel (Ed.), The Oxford encyclopedia of LGBT politics and policy. New York: Oxford University Press.

Camara, F. K. (2007-2008). Ce délit qui nous vient d'ailleurs: l'homosexualité dans le Code pénal du Sénégal. Psychopathologie africaine, XXXIV(3), 317-342.

Camminga, B. (2019). Transgender refugees and the imagined South Africa: Bodies over borders and borders over bodies. New York: Palgrave MacMillan.

Carrillo, H. (2004). Sexual migration, cross-cultural sexual encounters, and sexual health. Sexuality Research \& Social Policy, 1(3), 58-70.

Carrillo, H. (2017). Pathways of desire: The sexual migration of Mexican gay men. Chicago: The University of Chicago Press.

Chimni, B. S. (2004). From resettlement to involuntary repatriation: Towards a critical history of durable solutions to refugee problems. Refugee Survey Quarterly, 23(3), 55-73.

Choplin, A. (2010). 'Quand la mer se ferme': du transit au post-transit migratoire en Mauritanie. Hommes \& migrations, 1286-1287, 74-85. 
CNLS (2018). Rapport annuel 2018. Dakar: CNLS.

Davies, T., Isakjee, A., \& Dhesi, S. (2017). Violent inaction: The necropolitical experience of refugees in Europe. Antipode, 49(5), 1263-1284.

Fassin, D. (2000). Entre politique du vivant et politique de la vie: pour une anthropologie de la santé. Anthropologie et sociétés, 24(1), 95-116.

Fassin, D., \& d'Halluin, E. (2005). The truth from the body: Medical certificates as ultimate evidence for asylum seekers. American Anthropologist, 107(4), 597-608.

Fassin, É., \& Salcedo, M. (2015). Becoming gay? Immigration policies and the truth of sexual identity. Archives of Sexual Behavior, 44(5), 1117-1125.

Foucault, M. (2003 [1997]). 'Society must be defended': Lectures at the Collège de France, 197576. New York: Picador.

Fresia, M. (2009). Les Mauritaniens réfugiés au Sénégal: une anthropologie critique de l'asile et de l'aide humanitaire. Paris: L'Harmattan.

Fresia, M., \& von Känel, A. (2016). Universalizing the refugee category and struggling for accountability: The everyday work of eligibility officers within UNHCR. In K. L. Jacobsen, K. B. Sandvik (Eds.), UNHCR and the struggle for accountability (p. 101-118). Abingdon - New York: Routledge.

Garnier, A. (2016). Narratives of accountability in UNHCR's refugee resettlement strategy. In K. L. Jacobsen, K. B. Sandvik (Eds.), UNHCR and the struggle for accountability (p. 64-80). Abingdon - New York: Routledge.

Giametta, C. (2017). The sexual politics of asylum: Sexual orientation and gender identity in the UK asylum system. Abingdon - New York: Routledge. 
Haritaworn, J., Kuntsman, A., \& Posocco, S. (2014). Introduction. In J. Haritaworn, A. Kuntsman, S. Posocco (Eds.), Queer necropolitics (p. 1-27). Abingdon - New York: Routledge. Human Rights Watch (2020). Mauritania: Prison terms for men celebrating birthday. Prosecutor accused them of 'imitating women'. Human Rights Watch, https://www.hrw.org/news/2020/02/07/mauritania-prison-terms-men-celebrating-birthday.

Jacobsen, K. L., \& Sandvik, K. B. (2016). Introduction: Quest for an accountability cure. In K. L. Jacobsen, K. B. Sandvik (Eds.), UNHCR and the struggle for accountability (p. 1-25). Abingdon - New York: Routledge.

Kanno-Youngs, Z., \& Shear, D. M. (2019). Trump slashes refugee cap to 18,000, curtailing U.S. role as haven. New York Times, https://www.nytimes.com/2019/09/26/us/politics/trumprefugees.html.

Krause, U. (2017). Researching forced migration: Critical reflections on research ethics during fieldwork. Working Paper Series No. 123. Oxford: Refugee Studies Centre.

Laborde-Balen, G., Taverne, B., Ndour, C. T., Kouanfack, C., Peeters, M., Ndoye, I., \& Delaporte, É. (2018). The fourth HIV epidemic. The Lancet Infectious Diseases, 18(4), 379-380.

Lammers, E. (2007). Researching refugees: Preoccupations with power and questions of giving. Refugee Survey Quarterly, 26(3), 72-81.

Leservoisier, O. (2008). Les héritages de l'esclavage dans la société haalpulaar de Mauritanie. Journal des africanistes, 78(1-2), 247-267.

Lesourd, C. (2008). Le mesrah: regard sur la 'culture matérielle du succès' à Nouakchott. L'Année du Maghreb, IV, 325-338.

Lesourd, C. (2010). Bouche en cœur, battement de cils et tête à l'envers: rencontres et flirts à Nouakchott (Mauritanie). L'Année du Maghreb, VI, 147-169. 
Luibhéid, E. (2008). Queer/migration: An unruly body of scholarship. GLQ: A Journal of Lesbian and Gay Studies, 14(2-3), p. 169-190.

Mbembe, A. (2003). Necropolitics. Public Culture, 15(3), 11-40.

Menetrier, A. (2019). Déchiffrer les stéréotypes de genre aux guichets de l'asile. Hermès, 83, 179185.

Menetrier, A. (forthcoming). An ethical dilemma: When research becomes 'expert testimony'. Menetrier, A., \& Lawrance, B. N. (forthcoming). For better or worse: Marriage choices and asylum trajectories among LGBTI West African migrants.

Mose, K. N., \& Wriedt, V. (2015). Mapping the construction of EU borderspaces as necropolitical zones of exception. Birkbeck Law Review, 3(2), 278-304.

Murray, D. A. B. (2015). Real queer: Sexual orientation and gender identity refugees in the Canadian refugee apparatus. London: Rowman \& Littlefield International.

Musso, S. (2012). Être régularisé au titre de la maladie en France. Corps, 10, 153-161.

Newland, K. (2002). Refugee resettlement in transition. Washington: Migration Policy Institute. Nguyen, V.-K. (2005). Antiretroviral globalism, biopolitics, and therapeutic citizenship. In A. Ong, S. J. Collier (Eds.), Global assemblages: Technology, politics, and ethics as anthropological problems (p. 124-144). Malden: Blackwell Publishing.

OHCHR (2011). Discriminatory laws and practices and acts of violence against individuals based on their sexual orientation and gender identity: Report of the United Nations High Commissioner for Human Rights.

PNUD, HCDH (forthcoming). Orientation sexuelle, identité de genre et droits humains en Afrique: Rapport du Sénégal. Une revue et analyse participative de l'environnement juridique, social et 
des droits humains des personnes de diverses orientations sexuelles et identités de genre-Rapport 2018.

Puar, J. K. (2007). Terrorist assemblages: Homonationalism in queer times. Durham - London: Duke University Press.

Raboin, T. (2017). Discourses on LGBT asylum in the UK: Constructing a queer haven. Manchester: Manchester University Press.

Ribot, J. C., \& Peluso, N. L. (2003). A theory of access. Rural Sociology, 68(2), 153-181.

Saleh, F. (2020a). Queer/humanitarian visibility: The emergence of the figure of the suffering Syrian gay refugee. Middle East Critique, 29(1), 47-67.

Saleh, F. (2020b). Transgender as a humanitarian category: The case of Syrian queer and gendervariant refugees in Turkey. TSQ: Transgender Studies Quarterly, 7(1), 37-55.

Shakhsari, S. (2014a). Killing me softly with your rights: Queer death and the politics of rightful killing. In J. Haritaworn, A. Kuntsman, S. Posocco (Eds.), Queer necropolitics (p. 93-110). Abingdon - New York: Routledge.

Shakhsari, S. (2014b). The queer time of death: Temporality, geopolitics, and refugee rights. Sexualities, 17(8), 998-1015.

Sow, K., \& Desclaux, A. (2002). L'observance des traitements antirétroviraux et ses déterminants: analyse qualitative. In A. Desclaux, I. Lanièce, I. Ndoye, B. Taverne (Eds.), L'initiative sénégalaise d'accès aux traitements antirétroviraux: analyses économiques, sociales, comportementales et médicales (p. 109-118). Paris: Éditions ANRS.

Streiff-Fénart, J., \& Poutignat, P. (2006). De l'aventurier au commerçant transnational, trajectoires croisées et lieux intermédiaires à Nouadhibou (Mauritanie). Cahiers de la Méditerranée, 73, 129149. 
Taverne, B., Desclaux, A., Delaporte, É., \& Ndoye, I. (2014). Impact à long terme des traitements antirétroviraux en Afrique, état des connaissances. Bulletin de la Société de pathologie exotique, CVII(4), 222-229.

Ticktin, M. (2006). Where ethics and politics meet: The violence of humanitarianism in France. American Ethnologist, 33(1), 33-49.

Ticktin, M. (2011). Casualties of care: Immigration and the politics of humanitarianism in France. Berkeley: University of California Press.

UNHCR (2007). Chapter 7: Durable solutions - The 10-point plan (p. 183-206). Geneva: UNHCR.

UNHCR (2008). UNHCR guidance note on refugee claims relating to sexual orientation and gender identity. Geneva: UNHCR.

UNHCR (2012). Guidelines on international protection No. 9: Claims to refugee status based on sexual orientation and/or gender identity within the context of article 1A(2) of the 1951 convention and/or its 1967 protocol relating to the status of refugees. Geneva: UNHCR.

UNHCR (2015). Protecting persons with diverse sexual orientations and gender identities: A global report on UNHCR's efforts to protect lesbian, gay, bisexual, transgender, and intersex asylum-seekers and refugees. Geneva: UNHCR.

UNHCR (2016). Frequently asked questions about resettlement. Geneva: UNHCR.

Wade, A. S., Kane, C. T., Diallo, P. A. N., Diop, A. K., Gueye, K., Mboup, S., Ndoye, I., \& Lagarde, E. (2005). HIV infection and sexually transmitted infections among men who have sex with men in Senegal. AIDS, 19(18), 2133-2140.

Yue, A. (2008). Gay Asian sexual health in Australia: Governing HIV/AIDS, racializing biopolitics and performing conformity. Sexualities, 11(1-2), 227-244. 